\title{
Why Feminist Dissent?
}

\author{
Rashmi Varma*, Sukhwant Dhaliwal*, and Chitra Nagarajan* \\ *Correspondence: [Rashmi.Varma@warwick.ac.uk; \\ dhaliwal.sukhwant@gmail.com; chitra.rao.nagarajan@gmail.com]
}

\section{Abstract}

This essay lays out the historical and intellectual lineage of the idea behind the journal Feminist Dissent. As the "Rushdie Affair" was both the backdrop and the catalyst for a group such as Women Against Fundamentalism, the current conjuncture characterized by an exponential expansion of fundamentalism, neo-liberal austerity, rollback of the rights of women and sexual minorities, and racist control of borders and migration has necessitated a different kind of analysis, one that is absent from academic and popular discourse at the moment. This essay is an attempt to propose a new way of looking at the intersection of gender and fundamentalism,

Peer review: This article has been subject to a peer review process

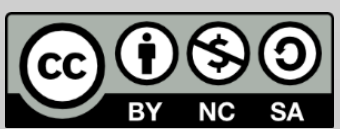

(c) Copyright: The Authors. This article is issued under the terms of the Creative Commons Attribution NonCommercial Share Alike License, which permits use and redistribution of the work provided that the original author and source are credited, the work is not used for commercial purposes and that any derivative works are made available under the same license terms. and underscores the importance of highlighting dissent as a crucial feminist strategy.

Keywords: fundamentalism, anti-racism, anti-imperialism, dissent, "war on terror", feminism

Feminist Dissent's intellectual genesis lies in the activist and theoretical work produced by the group Women Against Fundamentalism (WAF), a feminist antiracist and anti-fundamentalist group that was established in London in 1989, as well as in the political, journalistic, creative and academic work pursued by individual members of our editorial collective, only some of whom have been 
directly involved with WAF. WAF was formed in the wake of what has come to be known as "the Rushdie affair", in which following the publication of Salman Rushdie's novel The Satanic Verses, there emerged a transnational consolidation of religious fundamentalist forces from India to Bangladesh, from Britain to Iran and elsewhere. The fatwa issued by Iran's Ayatollah Khomeini against Rushdie in February 1989 seeking the author's death for the crime of blasphemy had been preceded by a ban of the book in India as it was perceived to be offending the faith of its Muslim minorities, and by demonstrations in Bradford, London and elsewhere in the UK. The book was publicly burnt and demands of death for Rushdie were made vociferously in retaliation for what was perceived as an insult to Muslims everywhere.

In defence of Rushdie's right to write, members of WAF asserted their own right to speak for themselves, to gender equality within communities, to diversity in religious practice and interpretation, to syncretism over purity, and to the right to question religious authority. For the Rushdie affair had brought to the fore an array of so-called community leaders, almost all male and many with dubious pasts in the Indian subcontinent, who used the moment to carve out a radical presence within the public sphere in Britain. They posed as representatives of minority immigrant communities, Britain's racialised others who were under attack in Thatcher's Britain. Indeed, some of the mainstream media coverage of the anti-Rushdie demonstrations portrayed the protestors as barbaric while some others likened them to Nazis, even as the National Front launched its own racist and xenophobic attacks on Asian communities. ${ }^{1}$

As South Asian fundamentalist community leaders came to dominate the public terrain and accrued legitimacy as 'representatives' of their communities, 
feminist activists saw a different power situation emerging, caught as they were between British racism and their own communities' social conservatism and growing fundamentalism. Many of the male voices to emerge in the wake of the Rushdie affair belonged to those who practiced profound gender conservatism, and whose idea of a pure culture and religion untarnished by the so-called 'West' while living in it was centrally organized around the idea of women as bearers of tradition. Those women who did not conform to their conservative vision were ostracized, demonised, and even killed. Moreover, these dominant voices, that also included second-generation Asian men who had participated in anti-racist movements, left no space to question or to dissent from the sexual norms and mores that governed these right-wing religious political mobilisations that were now curiously coalescing with seemingly progressive anti-racist positions, united in their understanding of women as objects of protection.

The founding of WAF was premised on the understanding that the form of gender politics that was laid bare during the Rushdie affair was not unique to Muslim communities, and that WAF's work had to focus on fundamentalism as a rising powerful force within all religions. ${ }^{2}$ For at the same time, a similar consolidation of fundamentalist tendencies was gaining ground globally. In the United States of America, a resurgent Christian fundamentalism focused attention on the teaching of evolution in schools and consolidated its assault on gay and lesbian movements, women's right to abortion, and other issues that were becoming central to the 'culture wars' of the ' 80 s and '90s, with the close association of the Christian Coalition, Moral Majority and other groups with the Republican Party. The Christian right was also perpetrating attacks on reproductive rights in Ireland and elsewhere, while Hindu fundamentalism's rise led to its social and political consolidation in India from the late 1980 s via the 
propagation of a vision of retrograde womanhood in the service of Hindu nationalism. There the renewed popularisation of the image of 'bharat mata', or the Indian nation as woman, led to a reinforcement of the idea that Hindu women need to be protected from rapacious Muslim 'outsiders' (Sarkar, 2001; Mazumdar, 1992). The Hindu supremacist mobilization that took place from the late 1980 s onwards for the first saw time included substantial participation by Hindu women as activists for the cause of the Hindu nation (Sarkar and Butalia, 1993).

Thus, WAF defined religious fundamentalism as a modern political movement and ideology seeking to consolidate power either within or in opposition to the state. In this, WAF made a crucial distinction between religious fundamentalism and religious observance, which it saw as a matter of personal choice. From its perspective, individuals have every right to follow any religious faith of their choice, or not to have faith at all, as long as their faith does not impinge on a gender just public space. On this view, it is secularism that offers the strongest guarantee of equality, of justice, and of equal access to the public, while leaving space for individual religious belief and unbelief.

\section{Two and a half decades later...}

Two and a half decades after WAF was first formed, we launch Feminist Dissent. The publication of the journal comes at a time when fundamentalism has spread its tentacles even deeper into our social and political lives and spaces. The impact of fundamentalism is being felt at a scale and in areas not previously known, such as the rise in Buddhist militancy in Burma, Sri Lanka and Thailand. ${ }^{3}$ In fact, what 
has been marked in recent decades has been the coming together and networking of cross-border and transnational religious, including fundamentalist, forces. The Sri Lankan Bodu Bala Sena's visit to Thailand and Burma in March 2014 to discuss strategy towards Muslim minorities, the Nigerian super churches' expansion into Sierra Leone having used the outbreak of Ebola as an entry point, and the sharing of tactics, inspiration, training and weapons between Islamist groups and the influence of Christian fundamentalist networks in African countries is indicative that fundamentalism is well on the rise globally. The ongoing murders of atheists and rationalists in Bangladesh, and the spectacular terror attack on an upscale restaurant in the country's capital city Dhaka on $1^{\text {st }}$ July 2016 in which about twenty six people were brutally killed, seem to be the handiwork of both local and transnational Islamist organisations, such as the terror outfit Aquis, the South-Asia Al-Qaeda affiliate, based in Pakistan (Ahmed, 2016).

On a different ideological and political level, the Vatican exploits its status as a state to influence issues concerning women's rights and the rights of sexual minorities. It works through local, national and transnational agents, both through the state and through civil society. We saw at CEDAW (the Convention on the Elimination of all Forms of Discrimination Against Women) the Vatican's ability to work in alliances when need be, especially when it came to curtailing reproductive rights. ${ }^{4}$ Our argument is against the view then that fundamentalists are just mavericks, alienated from society, and general misfits. The case of how the Vatican furthers a fundamentalist agenda directly antithetical to women's rights shows how fundamentalists clearly work in and through alliances. At the treaty level, 
the Vatican, together with some Catholic majority countries such as Poland and Ireland, pushed for (but failed) to get language around God, Jesus Christ or Europe's 'Christian heritage' in the Treaty Establishing a Constitution for Europe (2004). The Vatican also joined with a core group of Islamic states to oppose the proposals of the Women's Caucus for Gender Justice during the treaty negotiations leading to the Rome Statute of the International Criminal Court (1999) (Beldont and Martinez, 1999). After all, few delegations were willing to expend political capital on this issue and it is unlikely there would have been any integration of a gender perspective in the Rome Statute at all without the actions of the Women's Caucus.

This alliance building is most notable in recent struggles over the Commission on the Status of Women. Set up to review and push for implementation of the Beijing Platform for Action for Equality, Development and Peace (1995) and advance women's rights, in 2012, delegates could not even agree on a final communiqué as a result of a cross regional alliance including the Vatican, Iran, Syria and Russia which is not only blocking progress but making it difficult to even cling on to the gains so far. Sticking points include mention of women's sexual and reproductive rights, femicide, intimate partner violence, violence against women human rights defenders, violence against women based on sexual orientation or gender identity and early and forced marriage. Indeed, proposals for a conference twenty years on from the 1995 Fourth World Conference in Beijing met strenuous opposition from women's rights groups and supportive governments precisely because of the likelihood of it leading to a rollback rather than progression in agreements on women's rights at the international stage. Other recent developments - such as convictions of women for procuring their own abortions in countries including Argentina, Northern Ireland and Papua New 
Guinea - have been the result of an alignment of fundamentalist mobilisations and nation states.

As shown by the most recent Freedom of Thought Report (IHEU, 2015), the freedom to dissent from religion and faith altogether seems to be shrinking in many contexts, whether this is as a result of fear of conviction for apostasy, death threats and assassinations by non-state actors, or societal pressure to be religious. So the numbers fleeing persecution because of religion, belief or nonbelief are increasing while borders are closing and international obligations towards refugees and asylum seekers are, in practice, being rescinded. ${ }^{5}$

Many states have taken approaches in respect to fundamentalist groups that are disproportionately militarised, violate human rights and fall discriminatorily on one community. ${ }^{6}$ The discourse in European states around refugees and migrants within or at their borders is laced with fears of infiltration by ad-Dawlah al-Islāmiyah (commonly known as Islamic State) fighters and of 'being swamped' by large numbers of Muslims, to the extent that some politicians in "Fortress Europe" have resorted to exploiting the threatening idea of "Eurabia", the image of a Europe swamped by "Arab" migrants (Ferguson, 2004). The recent victory of the Brexit referendum in the UK has further exacerbated anti-immigrant sentiment and has unleashed racism and xenophobia on a large scale (Khaleeli, 2016).

\section{Disturbing alliances}

The consolidation of fundamentalism globally at the same time as there is increasing control of borders and migration, often along race and class lines, and 
of a worldwide financial crisis that spurred a wave of austerity measures across the globe, has exposed a deep chasm in progressives' thinking about gender and race, together, as deeply articulated and intersectional, blurring the lines between anti-imperialism and a defence of minority authoritarianism (Tax, 2013). Sukhwant Dhaliwal and Nira Yuval-Davis (2013) describe the 'contradictory pressures' that WAF historically faced, and that anti-fundamentalist and antiracist feminists everywhere have to confront today. They write: 'on the one hand (it/they) is/are faced with a growing majoritarian politics of belonging that is exclusionary and often anti-Muslim, and draws on either civilizational or Christian fundamentalist discourses. On the other hand, it is confronted by an undercutting of secular and other emancipatory movements by fundamentalist absolutist and authoritarian political projects in all religions. What's more, these latter projects are also connected to a growing identity politics among some minorities (especially but not only Muslims) that often utilize human rights and antiimperialist discourses. All of this is taking place within a local and global crisis of neoliberal political economy and a securitarian "war on terrorism"' (8).

In taking such a complex stand, feminists struggling for secular public spaces have often been accused of fuelling racism and imperialism, and of being 'western', deracinated secularists (Oza, 2011; Kumar, 2014). These are accusations that continue to be levelled against activists, particularly women, who fight against fundamentalism and for the realisation of rights. Indeed, the voices of activists fighting against fundamentalist forces and state actions, often at the same time, continue to be marginalised from public discussion. Debate, particularly around violent extremism, often follows simplistic lines of being for human rights/ against racist policies, practices and discourse or for security and protection of civilians. This journal aims to redress this imbalance, providing 
space for discussion of gender and fundamentalism, including competing viewpoints, and highlighting the voices of activists and showcasing new research initiatives.

Such attacks on secular feminists underscore a profoundly disturbing emergence of contradictory alliances of politics and principles. For many on the Left, particularly in the global North, religious fundamentalists seem to be prosecuting a heroic anti-imperial struggle against the imperialist power of countries such as the US, UK and France. Further faced with unprecedented cuts in the social budget and a brutally enforced austerity regime on the domestic front, many in the Left have come to see religious fundamentalism as the lone force in the world that seems to be able to challenge the unilateral power of the imperial countries. ${ }^{7}$ For their part, fundamentalists have tended to exploit antiimperialist traditions to present themselves as radical anti-Western antiimperialists. Groups like Stop the War Coalition and the Respect Party in the UK have allied with fundamentalists to forge what they see as an anti-racist and antiimperialist agenda. What we want to underscore is that in doing so, a critique of fundamentalism and authoritarian communal and patriarchal practices, including and particularly of non-state actors, has been neglected in the name of culture, tradition and 'respect' for difference.

The unprecedented and catastrophic series of events, known as the 'war on terror', unleashed by the terrorist attack on the World Trade Center in September 11, 2001 was followed by a US and UK-led invasion of Afghanistan and Iraq, a political, military and economic move that drastically altered pre-existing international relations across the board and unleashed an unprecedented escalation of jihadi violence. For a vast majority of the international Left, the war 
on Iraq and Afghanistan was a form of "new imperialism" (Harvey, 2003), a new stage of the expropriation of the world's resources via military might, while the dramatic rise of violent extremism was a form of 'blowback'. ${ }^{8}$ The rhetoric of human rights and the fight against terrorism, for the Left, was a fig leaf for the West's neo-colonial greed.

Since the US-UK led invasion of Iraq and the 'war on terror', there has been a significant resurgence of interest in the power of western states. Academic responses to these issues have, on the whole, tended to highlight the instrumentalisation of rights-based frameworks, the hypocrisy of nation states, and a critique of the civilizational, imperialist and racist presumptions at the heart of these developments. However, it is curious that little has been said by antiracist and feminist academics on fundamentalism. Prominent feminist theorists seem to have been significantly moved by the 'war on terror', but they have turned away from secularism and validated religious political formations. They seem more fascinated by women's participation in religious political mobilisations and immersion in religious identity politics than the impact of fundamentalism on women and sexual minorities (see, for instance, Aune et al, 2008; Brown, 2008; Butler, 2008; Braidotti, 2008; Bracke, 2008; Contractor, 2012; Fadil, 2011; Mahmood, 2005; Razack, 2005). Indeed we are still very far from Karima Bennoune's (2008) carefully framed argument that we need a simultaneous critique of state torture and a much needed left, anti-racist, feminist and civil liberties critique of the perpetrators of terror.

Another problematic that is not that dissimilar to the Bush-Blair years and that has proved divisive among the international Left is the role of international intervention (Achcar, 2015; Prashad, 2016). ${ }^{9}$ Within days of the Paris attacks of 
November 2015, France began bombing Syria while Europe tightened its borders against Syrians, many of whom are fleeing the death game between religious absolutist Islamic State militants and an authoritarian Assad regime. A repetitive polarization in the debate between a focus on the duplicitous politicians involved in war mongering and the left critique of any form of state intervention has highlighted the sorts of limited vision and political possibility that has been the source of frustration for the members of Feminist Dissent editorial collective.

A simplistic anti-imperialist argument that shifts the attention away from a systematic analysis of fundamentalist movements to an emphasis on the role that western governments have played in exacerbating Islamist recruitment or financial support needs to be nuanced. The material reality of racism does mean that one has to simultaneously fight for the right to talk about Islamism and also highlight the racist rhetoric of 'fortress Europe'. The "race card" and the question of international intervention align within the recurring recourse to patriotic and nationalist discourses that place pressure to declare one's allegiance to the nation state without any sense that so called "British" values or "French" values are not the preserve of nation states or of nationalist projects. The idea of 'another Europe' suggests that these must be values linked to human rights frameworks, and anti-discrimination values that have been fought for and shaped by an array of civil society mobilisations and actors across the global South and equally by minorities in Britain and across Europe.

In part this retreat from criticism of religious fundamentalism is the consequence of what Chetan Bhatt (1999) has referred to as the 'cultural episteme' and is a reproduction of an earlier tendency to treat the ethnic minority subject as particularly fragile and as victim. The proliferation of academic and 
journalistic work on 'Islamophobia' as the leading issue of our times, and published by leading leftwing presses such as Haymarket and Verso, provides instances of this (Kumar, 2012; Kundnani, 2015). Muslim men and women challenging fundamentalism are placed in the double bind of being burdened by right wing assimilationist pressures to challenge fundamentalism within their communities and a simultaneous criticism by left wing forces for pandering to state agendas and imperialism when they do so.

\section{The Culture Wars}

The Left liberal defence of culture, religion and tradition, seen especially in its ambivalent response to attacks on freedom of expression in favour of a politics of hurt sentiments of religious minorities, as exemplified most recently in the responses to the Charlie Hebdo murders but going as far back as the Rushdie affair, has of course been conversely matched by the resurgent 'clash of civilisations' thesis popularised by the American political scientist Samuel Huntington (1996) and the rhetoric and policies of politicians of the West who feed into and propagate the language of 'Western ideals and values' as universal values that are fundamentally at odds with Muslim culture. In fact, the then US President George Bush used distinctively Christian imagery to characterise the invasion of Afghanistan as a 'crusade' and that he was on a God-given mission to save the world. ${ }^{10}$ Thus the so-called 'war on terror' was deemed to be the outcome of an irreconcilable clash of civilisations, in which the West's superior material and ideological position would eventually vanquish the barbaric and backward people that the invasions were targeting. It exploited the image of the helpless Afghan women needing protection, as well as contrasted the 
bureaucratised, sanitised and protective forms of masculinity of the international technocrats and military forces with the brutal, repressive and 'barbaric' masculinity of Taliban fighters.

The protection of human rights, particularly those of women and lesbian, gay, bisexual, trans and intersex (Igbti) people has also been used in political rhetoric justifying actions ranging from military invasions to increased surveillance on communities. The ways in which the empowered, female (Jewish) Israeli soldier is used as a counterpart to the helpless, veiled (Muslim) Palestinian woman or the phenomenon of 'pink washing' are also different manifestations of this instrumentalisation of human rights discourses. There is of course often justified scepticism as to whether concern for human rights is really the reason for military or diplomatic intervention, with sceptics highlighting human rights violations committed by countries such as the UK and USA themselves, and pointing to the inconsistency in their treatment of different countries (see Prashad, cited above).

In many cases, these dynamics are exacerbated by the fact that the list of invasions of countries of the Middle East, Africa and Asia by Western powers seems ever-expanding, or as policies such as economic sanctions have been levied by the international community on supposedly rogue regimes that then wreak havoc on their own populations. The US-led invasion of Iraq and Afghanistan had a devastating impact on the region, one that is still reverberating with ongoing consequences in terms of the numbers of deaths, disability, loss of livelihoods, destruction of economic development and the erosion of human rights. The recent release of the Chilcot Report/Iraq Inquiry in July 2016 passed a damning verdict on the then British Prime Minister Tony Blair's decision to attack 
Iraq by deliberately exaggerating the threat posed by Saddam Hussein and Iraq's weapons of mass destruction. ${ }^{11}$

It is also symptomatic of global power politics that the withholding of aid or military arms and other assistance because of concerns regarding human rights violations are often spun by conservative anti-imperialists as punishment for holding on to 'traditional values' and part of a Western agenda to 'make everyone like them.' This is exemplified in the visit of Barack Obama, President of the USA, to Senegal in 2013. Against a backdrop of increasingly contentious and polarised global debates on the human rights of Igbti people and US foreign policy, President Macky Sall of Senegal, in a move hailed by the national media, talked about the need for countries to not impose their values on others. He said: 'We don't ask Europeans to be polygamists. We like polygamy in our country but we can't impose it in yours' (Nossiter, 2013).

Such a solidification, reification and narrowing of culture and tradition as that unleashed by religious fundamentalism of all hues has to be juxtaposed with the influence of religious norms from the 'outside', as fundamentalist movements become increasingly transnational. So for example in northern Nigeria, while the culture of sexual relationships between unmarried couples was widespread and tolerated, the implementation of sharia law across northern states from 2000 onwards has sought to constrain and re-shape gender relations and matters of sexuality. Many of the earlier customs are now seen as transgressive, with charges of zina (criminalising sex outside marriage) being levelled at so-called perpetrators as women's sexuality is increasingly viewed as a source of immorality (Pereira, 2005). These social shifts are linked to the radicalisation of northern Nigerian Islam through its contact with zealous and fundamentalist 
Islamic sects in other parts of the world from the 1970s onwards, leading to more puritanical and stricter interpretations that had previously been played down (Best, 2001).

\section{UK Context}

In the UK context - the place where Feminist Dissent is founded and based-many contemporary themes, paradoxes and positions still chime with the key moments of WAF's formative years. The problems and paradoxes that were identified by WAF women within the context of an assimilationist Thatcherite government at home and resurgent religious political mobilisations across the globe were exacerbated by a New Labour government for whom religious organisations were a critical part of governance. Post 9/11 in particular, religious groups and religious identities became an important aspect of civil society mobilisations and counter narratives.

Thus, this twenty-first century is marked by what many of those involved with the Editorial Collective have referred to as 'multifaithism', a new religious settlement between states and populations. A multiculturalist practice based on the undemocratic negotiations of the state with an unelected layer of "community leaders" (often religious men) has bolstered the power of ethnic minority religious leaderships in the UK over a number of decades. The multiculturalist settlement slid into multifaithism whereby religion became the primary signifier of difference and therefore of the state's invocation of strategies for diversity management (Dhaliwal and Yuval Davis, 2013). 
Multifaithism has had the effect of extending, privileging and institutionalising religion in relation to state relations with individuals, communities and civil society. This institutionalisation of religion within both politics and public policy that began with the election of New Labour in 1997 persisted in their experiment with religious communitarianism even though it contradicted the party's own social democratic commitment to equality and nondiscrimination, and even though religious communitarianism directly contradicted Labour's post-2001 drive on community cohesion and preventing violent extremism. The growing significance of religion for government and for civil society was continued under first the Conservative- Liberal Democrat Coalition and then the Conservative Party. These tendencies are also reflected in the trajectories and contemporary contexts of other countries, especially those with colonial histories.

In the UK, there has never been a full separation of religion and state, and citizenship demands have been vented in the form of parity demands by minority religious groups as far back as the 1960s. Demands for the recognition of religious accommodation have also been fuelled by the legislative recognition of some religions as 'ethnic groups' - notably Sikhs and Jews under the Race Relations Act 1976. Prominent liberal political theorists such as Tariq Modood and Bhikhu Parekh continue to align with leaders of fundamentalist bodies (such as Iqbal Sacranie of the Jamaat-e-Islami led Muslim Council of Britain) to campaign through public inquiries like the Woolf Commission for the recognition of religion as a public good and a role for religion in public life. At the same time, sociology of religion scholars, the National Secular Society and the British Humanist Association are suggesting that religious identification and practice are on the decline while the view that religion should not play a significant role in the public 
sphere - in welfare services, political life and the state - is gathering pace (Brown, 2016; Voas and Crockett, 2005; Voas, 2013; Woodhead, 2016). Such a contradiction poses significant questions for this journal on why religion is nonetheless an increasing aspect of the structure of modern political and public life and of state governance. There also seems to be significant confusion about the definition and practice of what is referred to as 'secular' and 'secularism' and a frequent conflation of secular with the term 'atheist'. This has been apparent at our own seminar series where speakers have relied on diverse understandings of secularism. ${ }^{12}$ Feminist Dissent will grapple with these tensions and debates about what constitutes secularism and what specifically this means for gender norms and relations, sexuality, the ability to secure women's and girls' rights, for the feminist subject, and for developments in feminist theory.

What we have also seen emerge quite centrally are the majoritarian dimensions of electoral politics, as in Egypt and India, among other countries. Indeed, both Tony Blair and David Cameron have relied on support from religious networks for the reinvention of their respective political parties. For Blair these religious networks were concentrated on minority religious groups (Sikhs, Hindus and Muslims) while for Cameron and the more extremist wing of the Tory Party, Christian Evangelical networks have been an additional source of political opportunity (Brown, 2010; Cook, 2010; Doward, 2010). Many of these religious networks contain fundamentalist lobbies with very specific demands: under Blair a central focus was the push for central state funding for ethnic minority religious schools and the proliferation of particular versions of their religions through consultative mechanisms; under Cameron, a pro-life and anti-reproductive rights lobby gained a voice at the centre of government. While the Conservative Party's austerity agenda has led to a significant reduction in the number of specialist 
feminist services, Christian fundamentalism has been pushing through all manner of government spaces to validate a new wave of groups that are seemingly innocuous counselling and welfare organisations but are funded by US Christian fundamentalist networks pushing an anti-abortion agenda (Imkaan, 2016; Manjoo, 2015; Walby, 2012). Christian fundamentalists have also been quick to mobilise to gain political power in post-Brexit Britain as can be seen in the rise of Andrea Leadsom - the main Tory party challenger to Teresa May--who is part of a group called Christians in Parliament and organise Bible Study Groups.

Another recurring factor has been the widespread understanding of religion and religious institutions as essential sources of morality and as a form of social glue. This is in spite of increased information about diversity and dissent within religions, critique of religious morality, and the significant media attention to religious terrorism around the globe, from ethnic cleansing of Muslims and Christians by Hindu Right forces in India to the transnational Islamist terror networks right through to the bombing of abortion clinics by the Christian Right in the US. Moreover, this sense of religions as cohesive in a context of heightened panic about the 'breakdown of society' is closely tied to and strengthened by yet another, and potentially most important, factor since the turn of the century the realisation that state engagement with religious organisations can facilitate (rather than impede or challenge) the proliferation of neo-liberalism because, through shared political interests, relations between state and religious organisations can actually extend the influence of the state and particularly its soft policing function while simultaneously helping to contain or reduce its pastoral and welfare obligations. This insight began with Tony Blair's reinvention of communitarianism towards neo-liberal ends (Rose, 2001) and has continued with Cameron's Big Society. The notion of Big Society has manipulated the 
language of left politics to discursively embellish a return to voluntarism and the retraction of the state by getting "community" to "voluntarily" mop up the fallout of a neo-liberal retraction of the state in exchange for de-regulation (Coote, 2010). Religious organisations have been quick to jockey for attention under the Big Society agenda and to make pro-active use of the extension of free schools and other state policies. ${ }^{13}$

Very few academics have critiqued this process despite a burgeoning 'faiths literature' in the UK. Even fewer have really grappled with the way that fundamentalist organisations have worked through these spaces in order to gain legitimacy and institute new gendered norms. The UK faiths literature is largely a functionalist argument about the capacity and positive impact of religious partners in civil society initiatives. Moreover, it projects religious groups as important carriers of social capital and providers of welfare support, and also projects religion as 'cohesive', and 'faith communities' as central players in tackling 'radicalisation' (for instance Beaumont, 2009; Blond, 2010; Bretherton, 2010; Chapman 2012, Dinham, Furbey \& Lowndes 2009, Dinham, 2009; Dinham et al, 2006; Farnell, 2001; Glasman 2008 and 2010; Jawad, 2012 to name just a few). Any critical tendencies within this expansive body of knowledge are limited to accusations that the state is instrumentalising religious belief for its own gains. Very little has been said about the specific implications for women, for sexual and racialized minorities of the new multifaithism and /or the ways in which fundamentalist projects have made proactive use of these multiple spaces. ${ }^{14}$

Most recently, reactions to the government's Prevent agenda have oscillated between left / anti-racist critiques that focus on the power of the state and its securitarian agenda that not only extends the authoritarian arm of the state but 
also mobilises concerns about terrorism towards anti-immigration policies and racist sentiments [see Kundnani, 2007; McGhee, 2010] at the cost of discussing and debating fundamentalist recruitment within the UK. Critical questions remain unanswered about the role of intelligence when the extended reach of the state is not able to prevent attacks like the one in London on $7 / 7$, in Paris in 2015 and in Brussels in 2016, from taking place. Whose role is it to keep people safe if it isn't the role of the state, and if it is the role of the state then what does a state-supported anti-fundamentalist agenda look like?

On the same day as the Paris attacks in November 2015, the Indian Prime Minister Narendra Modi, who had played a controversial role in the Gujarat riots of 2002 in which over 2,000 Mulsims were killed under his watch as Chief Minister of the state, and who had been denied a visa by the UK until then, was greeted by large crowds at a packed Wembley Stadium event organized and financed by Indians living in the UK, including a number of elected Labour party politicians of Indian origin. The previous day, Modi had been subjected to a large demonstration during his visit to Downing Street. Those two days raised a number of questions that highlight some of the issues with which this journal seeks to contend. The Wembley event reflected popular appeal for a fundamentalist political project, its entanglements with nationalist sentiment and diaspora politics. The diverse organisations represented at the anti-Modi rally reflected the diverse interests that may, at various points, oppose fundamentalist politics, including other fundamentalists. But the way in which Sikh fundamentalists utilized these spaces in particular, standing both inside state discussions with Modi and on the frontline of the anti-Modi demonstration reflects both the diverse character of fundamentalist political projects and their sophisticated utilization of a range of different spaces. Moreover, the presence 
of Sikh fundamentalists at the anti-Modi rally raised a number of additional concerns about political alliances and re-emphasised the concern about diasporic financing for fundamentalist politics in South Asia. The fact that media attention to Modi's visit was usurped by a terrorist attack in Paris, which Modi himself utilized to lay claim to a language of universal opposition to terrorism, throws together a huge number of questions about the links between fundamentalism and violence, the location of power, the language of fundamentalism and antifundamentalism, as well as the ongoing utility of anti-Muslim racism, antiimmigrant sentiment and nationalism.

\section{Why Feminist Dissent?}

We believe that the task of Feminist Dissent is now more challenging than ever. Current events and trends that have been shaped and driven by shifts in religion, political identities and geopolitics over the past decades globally signal a seachange from the earlier period of decolonization in Africa and Asia when a vision committed to a secular, socialist and internationalist global society was articulated, as in the concept of tricontinentalism, or in the anti-racist counterculture energies of the 1960s and 1970s. In academia, postcolonial and postmodernist strands of critical inquiry and the dominance of cultural relativism whose critique of the Enlightenment as a racist and imperialist project, and a concomitant valorisation of the popular and the subaltern has led, ironically, to a retreat from a critique of religious fundamentalism and patriarchy. While we take on board the insights gained from materialist postcolonial theory that the 18th century Enlightenment was indeed instrumentalised in the hands of slave-owners and colonisers to justify European superiority, we draw inspiration from anti- 
colonial struggles that were fought by peoples throughout Asia and Africa in order to wrest concepts of freedom, liberty, rule of law, rights, secularism, etc. from the 'West'.

Thus, twenty-five years since the Rushdie Affair, the situation seems both more complex yet also more straightforward. Firstly, the interrelation between gender and fundamentalism needs to be viewed in the context of societal and global shifts over the last two and a half decades that include the retreat of the state globally from the social sector, growing atomisation caused by migration to cities and displacement from the countryside, as well as the constant state of war over terror and resources. Indeed, the failure of the state to provide social security has contributed to the increasing importance of non-state actors, including those organised around faith lines, to fill the gap within social well being. Meanwhile, women often join religious extremist forces for similar reasons as men, as well as a way to gain some power, freedom and access to religious knowledge denied to them by more mainstream religious and cultural mores (Ladbury, 2015). ${ }^{15}$ There is also an ironic link to situations where, for example, the abductions in northern Nigeria in recent years bear more similarity to abductions by the Lord's Resistance Army, a rebel and cult group operating in northern Uganda, South Sudan, the Central African Republic and the Democratic Republic of Congo, than to other violent fundamentalist movements motivated by Islam. Furthermore, religion, along with other identity markers such as ethnicity and occupational groups, has been instrumentalised in conflict to mobilise communities to 'their' cause. Indeed, these factors have been playing an increasingly greater role in conflicts and violence than before, linked to shifts in the politicisation of these identities and with the complicity and encouragement of state and non-state actors. Forms of Islamic fundamentalism 
have become almost synonymous with fundamentalism itself for many politicians and commentators. Yet entire Muslim communities are implicated in this and such a narrative fails to see the commonalities with other forms of religious fundamentalism, often not framed as fundamentalism or seen as essentially different. It also fails to take a global perspective.

We find that in contrast to dominant academic and international NGO-driven work, progressive movements on the ground often have stronger analyses of fundamentalism, and seek to combat its influence and impact, as well as seek to highlight progressive interpretations of religion and engender changes in religious, state and cultural institutions (Zia, 2011). After all, feminist activists, whether in India or Nigeria or Turkey, or in Latin American countries, in their activism have historically embraced ideas of freedom, secularism and rights and have a much more nuanced understanding and navigation of the terrain of colonialism, racism and rights than often seen in the West. They ask the question: are we to cede all of these ideas to Western imperialism? We argue that the history of anti-colonial struggles in fact has been precisely that-to wrench these concepts from their European moorings and to re-signify them for anti-colonialist and progressive aims. As such, a key aim of Feminist Dissent is to query the gap between academic and activist work, and to ask crucial questions about why such a gap exists.

We call it Feminist Dissent because as feminists we dissent both from the fundamentalist and neo-liberal political forces seeking to control our worlds today, but also from large strands within dominant theory and activism, especially as institutionalised in the Western academy, that have not provided consistent secular and progressive responses to ongoing global economic and 
political crises that include a resurgent fundamentalism and attacks on a secular feminist public sphere.

Rashmi Varma teaches English and Comparative Literary Studies at the University of Warwick. She is the author of The Postcolonial City and its Subjects (2011) and of the forthcoming Modern Tribal: Representing Indigeneity in Postcolonial India.

Sukhwant Dhaliwal is a Research Fellow and PGR Co-ordinator at the Institute of Applied Social Research, University of Bedfordshire. With Nira Yuval Davis, she is co-editor of Women Against Fundamentalism: Stories of Dissent and Solidarity (Lawrence \& Wishart, 2013).

Chitra Nagarajan is an activist who has worked to promote and protect human rights, particularly those of women, in China, the United Kingdom, the United States and west Africa. She currently works to build peace in Nigeria. She writes a blog based on her work and activism.

\section{References}

Achcar, G. (2015)"A Masterclass in Sophistry: Patrick Cockburn on the Russian intervention in Syria". Pulse, October 4. [online] Available from: https://pulsemedia.org/2015/10/04/a-masterclass-in-sophistry-patrickcockburn-on-the-russian-intervention-in-syria/ (Accessed on 6 July 2016).

Ahmed, I. (2016) "Dhaka terror attack: Bangladesh pays the price for its government's policy of appeasing Islamists", Scroll.in. [online] Available from: http://scroll.in/article/811039/dhaka-terror-attack-bangladesh-pays-the-priceof-its-governments-policy-of-appeasing-islamists (Accessed on 6 July 2016).

Amnesty International. (2014) The Human Cost of Fortress Europe: Human Rights Violations Against Migrants and Refugees at Europe's Border. London: Amnesty International Ltd. [online] Available from: http://www.amnesty.eu/content/assets/Reports/EUR 050012014 Fortress E urope complete web EN.pdf (Accessed on 18 July 2016)

Aune, K., Sharma, S. and Vincett, G. (2008) Women and Religion in the West: Challenging Secularisation. Ashgate: Aldershot and Burlington. 
Bennoune, K. (2008) "Terror/Torture". In Berkeley Journal of International Law 26: 1 - 61.

Beaumont, J. (2008) "Faith Action on Urban Social Issues". In Urban Studies 45(10): 2019.

Best, S. G. (2001) "Religion and Religious Conflict in Northern Nigeria". University of Jos Journal of Political Science. 2(3); 63-81.

Bhatt, C. (1999) "Ethnic Absolutism and the Authoritarian Spirit". In Theory, Culture \& Society April 1999 vol. 16 no. 2, 65-85.

Blond, P. (2010) Red Tory: How the Left and Right Have Broken Britain and How We Can Fix It. Faber and Faber Limited.

Bracke, S. (2008) "Conjugating the Modern/ Religious, Conceptualizing Female Religious Agency: Contours of a 'Post-secular' Conjuncture”. In Theory, Culture \&

Society 25(6): 51-67.

Braidotti, R. (2008) "In Spite of the Times: The Postsecular Turn in Feminism". In Theory, Culture \& Society 25(6): 1-24.

Bretherton, L. (2010) Christianity and Contemporary Politics: The Conditions and Possibilities of Faithful Witness. Chichester: Wiley-Blackwell.

Brown, A. (2010) "Tories and the New Evangelical Right". The Guardian. [online] Available from:

http://www.guardian.co.uk/commentisfree/andrewbrown/2010/may/10/evang elical-religion-tory-conservatives (Accessed 3rd July 2016).

Brown, A. (2016) "No religion is the new religion" The Guardian. [online] Available from: https://www.theguardian.com/commentisfree/2016/ian/20/noreligion-britons-atheism-christianity (Accessed 3rd July 2016).

Brown G (2003) "Equality-Then and Now". In A. Chadwick and R. Heffernan (eds). The New Labour Reader. Polity Press Limited. 
Brown, W. (2008) Regulating Aversion: Tolerance in the Age of Identity and Empire. USA: Princeton University Press.

Butler, J. (2008) "Sexual Politics, Torture, and Secular Time". In The British Journal of Sociology 59(1): 1-23.

Centre for Contemporary Cultural Studies (1982) The Empire Strikes Back: Race and Racism in 70's Britain. London: Routledge.

Chapman, R. (2012) Faith and Belief in Partnership: The Scope, Challenges and Methods of Effective Collaboration with Local Government. London: Local Government Improvement and Development Agency (LGID).

Contractor, S (2012) Muslim Women in Britain: De-Mystifying the Muslimah. London: Routledge.

Cook, C. (2010) "Christian Tories Rewrite Party Doctrine". In The Financial Times.

[online] Available from: https://next.ft.com/content/12400596-16ac-11df-aa0900144feab49a (Accessed $3^{\text {rd }}$ July 2016).

Coote, A. (2010) "Cameron's 'empowerment' scam". In openDemocracy. [online] Available from: http://www.opendemocracy.net/ourkingdom/annacoote/camerons-empowerment-scam (Accessed 3rd July 2016).

Democracy Now! (2014). "Blowback: Vijay Prashad on How Islamic State Grew Out of U.S. Invasion of Iraq, Destruction of Nation". [online] Available from: http://www.democracynow.org/2014/8/25/blowback vijay prashad on how i slamic state (Accessed 6 July 2016)

Dhaliwal, S. and Patel, P. (2012) "Feminism in the Shadow of Multi-faithism: the Implications for South Asian Women in the UK". In Roy, S. (ed). South Asian Feminisms: Paradoxes and Possibilities. London: Zed Books.

Dhaliwal, S. and Yuval-Davis, N. eds. (2014) Women Against Fundamentalism: Stories of Dissent and Solidarity. London: Lawrence and Wishart. 
Dinham, A., Furbey, R. and Lowndes, V. eds. (2009) Faith in the Public Realm: Controversies, Policies and Practices. Bristol: The Policy Press.

Doward, J. (2010) "Secret Christian Donors Bankroll the Tories". The Observer.

[online] Available from:

http://www.guardian.co.uk/world/2010/may/02/secret-christian-donorsbankroll-tories (Accessed $3^{\text {rd }}$ July 2016).

Fadil, N. (2011) "Not-/Unveiling as an Ethical Practice". In Feminist Review 98(1): 83-109.

Farnell R. (2001) "Faith Communities, Regeneration and Social Exclusion: Developing a Research Agenda". In Community Development Journal 36(4): 263-272.

Ferguson, N. (2004) "The Way we Live Now: 4-4-04; Eurabia?" The New York Times Magazine. (Accessed on 6 July 2016).

Furbey, R., Dinham, A., Farnell, R., Finneron, D. and Wilkinson, G. (2006) Faith as Social Capital: Connecting or Dividing? Bristol: The Policy Press.

Glasman, M. (2008) “Abraham, Aristotle and Alinsky: On the Reconciliation of Citizenship and Faith". Faith and Citizenship: Friends or Enemies? London Metropolitan University.

Gupta, R. (2009) "An all-too familiar affair". The Guardian. [online] Available from:

https://www.theguardian.com/commentisfree/belief/2009/feb/20/rushdiefatwa-religion (Accessed on 28 June 2016).

Harvey, D. (2003) The New Imperialism. Oxford: Oxford University Press.

Huntington, S. (1996) The Clash of Civilisations and the Remaking of World Order. New York: Simon and Schuster.

Imkaan (2016) "Capital Losses: The state of the BME ending violence against women and girls sector in London". London: Imkaan. [online] Available from: https://www.dropbox.com/s/2h7zknmuh33zno9/Capital\%20Losses\%20\%20Imkaan\%20April\%202016.pdf?dl=0 (Accessed $3^{\text {rd }}$ July 2016). 
Jawad, R. (2012) Religion and Faith-Based Welfare in the UK: From Wellbeing to Ways of Being Bristol: The Policy Press.

Jefferys, S. (2011) "Desecularisation and Sexual Equality". In the British Journal of Politics and International Relations, Vol 13, 364-382.

Khaleeli, H. (2016) "'A frenzy of hatred': how to understand Brexit racism". The Guardian. [online] Available from:

http://www.theguardian.com/politics/2016/jun/29/frenzy-hatred-brexitracism-abuse-referendum-celebratory-lasting-damage (Accessed 6 July 2016)

Kumar, D. (2012) Islamophobia and the Politics of Empire. Haymarket Press.

-----, (2014) "Imperialist Feminism and Liberalism". openDemocracy. [online] Available from: https://www.opendemocracy.net/deepa-kumar/imperialistfeminism-and-liberalism (Accessed on 18 July 2016)

Kundnani, A. (2007) The End of Tolerance: Racism in 21st Century Britain. London: Pluto Press.

-----, (2015) The Muslims are Coming!: Islamophobia, Extremism and the Domestic War on Terror. London: Verso.

Macey, M. and Carling, A. (2011) Ethnic, Racial and Religious Inequalities: The Perils of Subjectivity. Basingstoke: Palgrave Macmillan.

Mahmood, S. (2005) Politics of Piety: The Islamic Revival and the Feminist Subject. USA: Princeton University Press.

Manjoo, R. (2015) Report of the Special Rapporteur on violence against women, its causes and consequences, on her mission to the United Kingdom of Great Britain and Northern Ireland (31 March-15 April 2014). UN General Assembly. [online] Available from:

http://www.endviolenceagainstwomen.org.uk/data/files/UNSR VAW UK repo

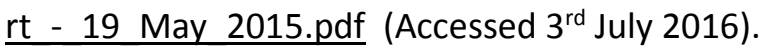

Mazumdar, S. (1992) "Women, Culture and Politics, Engendering the Hindu Nation". South Asia Bulletin, VOL. XII NO. 2, pp. 1-24. 
McGhee, D. (2010) Security, Citizenship \& Human Rights: Shared Values in Uncertain Times. Palgrave Macmillan.

Moghdam, V. ed. Identity Politics and Women: Cultural Reassertions and Feminisms in International Perspective. Boulder, CO: Westview Press.

Nossiter, A. (2013) "Senegal Cheers Its President for Standing Up to Obama on Same-Sex Marriage". New York Times. [online] Available from: http://www.nytimes.com/2013/06/29/world/africa/senegal-cheers-itspresident-for-standing-up-to-obama-on-same-sex-marriage.html? $r=0$ (Accessed July 18, 2016)

Oza, R. (2011) "With Us or Against Us". Counterpunch. [online] Available from: http://www.counterpunch.org/2011/01/21/with-us-or-against-us/ (Accessed 18 July 2016)

Patel, P. (2008) “Faith in the State? Asian Women's Struggles for Human Rights in the UK". In Feminist Legal Studies Volume 16 (1) April 2008: 9-36.

Patel, P. (2013) "Multifaithism and the Gender Question: Implications of Government Policy on the Struggle for Equality and Rights for Minority Women in the UK". In Yasmin Rehman, Liz Kelly and Hannana Siddiqui (eds). Moving in the Shadows: Violence in the Lives of Minority Women and Children. Surrey, England: Ashgate.

Pereira, C. (2005) "Zina and Transgressive Heterosexuality in Northern Nigeria". Feminist Africa. 5; 52-79

Prashad, V. (2016) "The New Façade for Regime Change: a Brief History of Humanitarian Interventionism". Counterpunch. [online] Available from: http://www.counterpunch.org/2016/06/02/the-new-facade-for-regime-changea-brief-history-of-humanitarian-interventionism/ (last accessed on 6 July 2016).

Razack, S. (2005) "Geopolitics, Culture Clash, and Gender After September 11". In Social Justice Vol. 32, No. 4 (102). Race, Racism, and Empire: Reflections on Canada pp. 11-31. 
Rose, N. (2001) "The Politics of Life Itself". In Theory, Culture \& Society, vol. 18 no. 6 pp 1-30.

Sarkar, T. (2001) Hindu Wife, Hindu Nation: Community, Religion, and Cultural Nationalism. Bloomington, Indiana: Indiana University Press, 2001.

Sarkar, T. and Butalia, U. eds. (1995) Women and the Hindu Right: A Collection Of Essays. New Delhi: Kali for women.

Tax, M. (2013) The Double Bind: The Muslim Right, the Anglo-American Left, and Universal Human Rights. London: Centre for Secular Space.

Towers, J. and Walby, S. (2012) Measuring the Impact of Cuts in Public Expenditure on the Provision of Services to Prevent Violence Against Women and Girls. Uk: Lancaster University. [online] Available from:

http://www.trustforlondon.org.uk/wp-content/uploads/2012/01/VAWG-CutsFull-Report.pdf (Accessed 3rd July 2016).

Voas, D. and Crocket, A. (2005) "Religion in Britain: Neither Believing nor Belonging" in Sociology, February 2005 vol. 39 no. 1 pp 11-28.

Voas, D. (2013) “Hard Evidence: Is Christianity Dying in Britain?" In The Conversation. [online] Available from: $\underline{\text { https://theconversation.com/hard- }}$ evidence-is-christianity-dying-in-britain-20734 (Accessed $3^{\text {rd }}$ July 2016).

Woodhead, L. (2016) "Why 'no religion' is the new religion". The British Academy. [online] Available from:http://www.britac.ac.uk/events/why-noreligion-new-religion (Accessed 3rd July 2016).

Yuval-Davis, N. (2013) "Religion and Gender in Contemporary Political Projects". In Niamh Reilly and Stacey Scriver (eds) Religion, Gender and the Public Sphere. London: Routledge.

Zia, A. S. (2011) “Donor-driven Islam?" openDemocracy. [online] Available from:https://www.opendemocracy.net/5050/afiyashehrbano-zia/donor-driven-islam (Accessed on 18 July, 2016). 


\section{Notes}

${ }^{1}$ For an account, twenty years later, of the Rushdie affair and WAF's founding, see Rahila Gupta (2016). See also Sukhwant Dhaliwal and Nira Yuval-Davis (2013). In it, many of the founders of WAF reflect on the moment of WAF's founding and its relevance twenty-five years later.

${ }^{2}$ For an excellent collection of essays on the resurgence of religious-based identity movements and its impact on gender issues, see Valentine Moghdam (1994).

3 The killing and displacement of the Rohingya Muslim minority in Burma/Myanmar, as well as the attacks against Christians and Muslims in Sri Lanka, are believed to be carried out by the Bodu Bala Sena (Buddhist Power Force). It has also demanded laws to protect Buddhism and its declaration as a state religion in Thailand.

${ }^{4}$ See WAF Journal No. 7, 1995, which had a specific focus on reproductive rights at the Beijing Conference. See http://womenagainstfundamentalism.org/wpcontent/uploads/2014/05/waf7.pdf

${ }^{5}$ See Amnesty International's report entitled The Human Cost of Fortress Europe: Human Rights Violations Against Migrants and Refugees at Europe's Border (London: Amnesty International Ltd, 2014) for a detailed account of the violations of human rights taking place on Europe's borders, including the deaths of thousands.

http://www.amnesty.eu/content/assets/Reports/EUR_050012014_Fortress_E urope_complete_web_EN.pdf

${ }^{6}$ For example, international human rights organisations and local activists have documented a number of human rights violations, including extrajudicial killings, torture, sexual violence and long-term detention without charge, committed by the Nigeria military (Amnesty International, 2015; Center for Civilians in Conflict, 2015.) The controversial Prevent agenda in the UK as a tactic to prevent "radicalisation" of Muslim youth is also seen as an attempt by the British state to make surveillance of minority ethnic communities legitimate. https://www.gov.uk/government/uploads/system/uploads/attachment data/fil e/97976/prevent-strategy-review.pdf See also the podcast of a workshop on Prevent organised by Feminist Dissent at the University of Warwick on 15 January 2016: https://www.youtube.com/watch?v=qE_Ig3G7KxA In India, there has been a spate of "encounter" killings and extrajudicial internments for those suspected of terrorism, especially in areas such as Kashmir and those under Maoist influence.

${ }^{7}$ The brutal murder of the cartoonists who ran the French satirical magazine Charlie Hebdo in January 2015 produced a deeply ambivalent response from the Left as well as from many liberals in the West, who saw the cartoonists as representatives of a secular West out of touch with the religious sentiments of France's disempowered and vulnerable Muslim population. The writer Rachel Kushner decried Charlie Hebdo's "cultural intolerance" and its promotion of "a forced secular view". See http://www.nytimes.com/2015/04/27/nyregion/sixpen-members-decline-gala-after-award-for-charlie-hebdo.html? $r=0$ (accessed on 28 June 2016)

8 "Blowback: Vijay Prashad on How Islamic State Grew Out of U.S. Invasion of Iraq, Destruction of Nation", Democracy Now! August 25, 2014. 
http://www.democracynow.org/2014/8/25/blowback vijay prashad on how i slamic state (last accessed 6 July 2016)

${ }^{9}$ Other vocal Left intellectuals against intervention are Tariq Ali and Patrick Cockburn. For a response to Tariq Ali's opposition to intervention in Syria, see the blogpost https://syriafreedomforever.wordpress.com/2015/11/30/responseto-tareq-ali-2015-or-the-need-for-internationalist-solidarity/. For a response to Cockburn's writing on Syria, see Gilbert Achcar (2015).

${ }^{10}$ See George Bush's speech at the White House soon after the attack on the World Trade Centre towers https://georgewbushwhitehouse.archives.gov/news/releases/2001/09/20010916-2.html for instances of how Bush used a language soaked in religious fervor and faith to drum up national support for the war.

${ }^{11}$ In Iraq alone, as of early May 2016, an estimated 242, 000 people have died following the 2003 invasion according to records that are publicly available and aggregated by Iraq Body Count. Of these an estimated 157,148 to 175, 862 are civilians. For a brief overview of the Iraq Inquiry, see https://www.theguardian.com/uk-news/2016/jul/06/iraq-inquiry-key-pointsfrom-the-chilcot-report (last accessed 18 July 2016)

12 These seminars can be viewed in full from our Events page at: http://www2.warwick.ac.uk/fac/arts/english/research/currentprojects/feminist dissent/events/

${ }^{13}$ See for instance the Jewish Leadership Council's policy paper (2010) Big Society and the UK Jewish Community available at: http://www.thejlc.org/newsite/wpcontent/uploads/2011/12/bigsociety.pdf [last accessed $3^{\text {rd }}$ July 2016].

${ }^{14}$ Notable exceptions include the journalistic posts on the Open Democracy Religion, Gender, Politics site and essays by Dhaliwal (2011), Dhaliwal and Patel (2012), Jefferys (2011), Macey and Carling (2011), Patel (2008 and 2013), and Yuval-Davis (2013).

${ }^{15}$ A study that interviewed young (18-35 years) former JAS members who had left the sect voluntarily found that religion and ideology was a thread that ran through many of their stories, with young women joining particularly to learn the Quran, knowledge denied to them given the low numbers of access to education for girls, and gaining higher status due to their roles in the group.

To cite this article:

Varma, R., Dhaliwal, S. \& Nagarajan, C. (2016). Why Feminist Dissent? Feminist Dissent, (1), pp. 1-32. Retrieved from:

http://journals.warwick.ac.uk/index.php/feministdissent/article/view/6 